\title{
THE RELATIONSHIP OF MOTIVATION, DIGITALIZATION AND FIRM'S PERFORMANCE: A STUDY OF WOMEN ENTREPRENEURS IN BANGALORE
}

\author{
Afsana Salam \\ Research Scholar, Presidency University, Bangalore, Karnataka. India \\ Dr. Vengalarao Pachava \\ Assistant Professor, School of Management, Presidency University, \\ Bangalore, Karnataka. India
}

\begin{abstract}
This study recommends conceptual frameworks that demonstrate the relationship of digitalization between motivation and firm performance of women entrepreneurs in Bangalore. The researcher selected Bangalore city for the primary data collection through the questionnaire, with a non-random sampling technique of 22 women entrepreneurs. The collected data were analyzed by using descriptive, inferential, and multiple regression analysis to test the performance of a business run by women in Bangalore. As a result of this conceptual model, digitalization was not a mediating variable in the relationship between the motivation and firm performance of women entrepreneurs. The direct effects of the individual variable are highly significant by the motivation to firm performance, motivation to digitalization, and digitalization to firm performance. The researcher suggests that the model shall be constructed as a moderating variable to attract the women entrepreneur's intention towards digitalization.
\end{abstract}

Key words: Women Entrepreneurship, Motivation, Digitalization, Firm performance, Digital Entrepreneur, Mediating variable.

Cite this Article: Afsana Salam and Vengalarao Pachava, The Relationship of Motivation, Digitalization and Firm's Performance: A Study of Women Entrepreneurs in Bangalore, International Journal of Management, 11(12), 2020, pp. 2252-2262.

http://iaeme.com/Home/issue/IJM?Volume=11\&Issue=12

\section{INTRODUCTION}

The term digital has been a major mode of recent researchers, it also persists in entrepreneurial activities. Digital has become a catchphrase to transform the utilities in all segments of the market. Entrepreneurship is the process of creating innovative business entities by individuals. 
The most important role of an entrepreneur is to initiate the transformation in the society that leads to a wider cultural shift. Ndinguri, (2013) examined the transfer that takes place with the trend, in digital entrepreneurship which is possessed by both men and women equally. Consistently, researchers highlighting facts of the technological growth and digitalization facilitate women's survival in the business who encounters several constraints such as social, economic and psychological factors (Aparicio et al., 2016; Örnek \& Danyal, 2015; Semrau et al., 2016; Simón-Moya et al.,2020; Yan, 2010). Few authors have also been able to draw on systematic research in different variables, such as family support (Abe et al., 2015), motivational factors (Krishnamoorthy \& Balasubramani, 2014), educational needs (Kain \& Sharma, 2013; William J Health, 1995), required different skills and training for women entrepreneur (Braun, 2008; Lorz, 2011), government support services(Yukongdi, 2020) to transform traditional homemaker(Haverson, 1993) to the successful leader who is aggressive, prominent and prepared to take the risk(Goyal \& Parkash, 2011). Collectively, these studies outline the critical task of women entrepreneurs. Conversely, far too little attention has been rewarded to achieve the following research objectives. This study is to blend the existing definitions of digitalization and motivation that effect entrepreneurial women to generate an innovative idea and/or to start a business. This study endeavor to provide an overview of the main topics studied under digitalization, motivation, firm performance and to identify the gaps in the literature reviews on the impact of digitalization and motivational factors which lead to successful entrepreneurial women in Bangalore.

\section{MOTIVATION}

Traditionally, women are known to be safe at home and the Indian society believes that as cultural facts (Hina, 2013). Even if they are motivated to start an entity, women intend to have a stereotypical business domain and with excessive labor force (Birley et al., 1987). Women persistently accept the challenges as an opportunity and create innovative ideas to develop their business (Abeh et al., 2015). A small number of reviews have also been able to draw on systematic research in different variables, such as family, pull and push inspiration factors (Dempsey, 2014), motivational factors (Krishnamoorthy \& Balasubramani, 2014), entrepreneurial traits, skills and knowledge (Baum \& Locke, 2004). The level of education qualification predominantly influences entrepreneurial activity (Pruett, 2012) and effectively resulted in the acceptance of technology (Lorz, 2011). This study highlights most of the important internal and external factors of motivation among women entrepreneurs.

\section{DIGITALIZATION}

The term technologies (Chaithralaxmi.T and Shruthi. N, 2016) may be determined as conducting an online transaction that includes e-commerce, online marketing, online payment, and cloud storage. A large and growing body of literature has investigated the term digitization, which refers to the core process of converting data from analog to digital. Whereas many of the definitions of the term digitalization have been suggested, this study determines to use the definition contributed by (Susan Moore, 2015) in Gartner referred, "as the use of technology in the entrepreneurial process". Many researchers (Ahmad Asadullah et al., 2018; Jason Bloomberg, 2018; Nambisan, 2017) reported that leaders and entrepreneurs are consistently establishing the term digitization and digitalization as a similar reference to the use of technology. As per the previous study (Birley et al., 1987) also recognized the need for training women, which may support the sustainable economy of the country. Digitalization motivates women entrepreneurs to start, grow, and to sustain in the competitive marketplace (Hina, 2013). 


\section{FIRM PERFORMANCE}

Women entrepreneur's firm was measured with the capability to identify the relationship between entrepreneurial ability and the outcome of the business performance (Mohammed et al.,2017; Zizile \& Tendai, 2018). Any new ventures with motivation highly significant in entrepreneurial success (Yan, 2010), with the adoption of information technology and the internet (Sugiharto et al., 2010) improves the productivity of SMEs and online services for making new market influences on business performance. The focus of the study is to analyze the mediating role of digitalization on entrepreneurship, linking with the level of motivation on women entrepreneur's firm performance (Abdul Al \& Mostafa, 2019; Afework et al., 2015).

\section{RESEARCH HYPOTHESIS}

This study attempts to demonstrate conceptual frameworks that the relationship of digitalization between motivation and firm performance of women who own or manage the business in Bangalore. Many studies (Hasan \& Almubarak, 2016; Krishnan \& Kamalanabhan, 2013; Sugiharto et al.,2010; Welsh et al.,2018; Yan, 2010) were conducted for the model of firm performance with different variables. For this study, motivation and digitalization are two of the independent variables influencing the firm performance of women entrepreneurs in Bangalore. Therefore, four research hypotheses formulate which are as follows:

H01: There is no significant relationship between motivation and firm performance of women entrepreneurs

H11: There is a significant relationship between motivation and firm performance of women entrepreneurs

The concept of entrepreneurial motivation describes the major influential factors for firm performance (Naffziger et al.,1994) to attain the target of women entrepreneurs. The opportunity identification is a major influencing factor on women entrepreneurs firm's performance (Hasan \& Almubarak, 2016) to participate in the business.

H02: There is no significant relationship between digitalization and the firm performance of women entrepreneurs.

H12: There is a significant relationship between digitalization and the firm performance of women entrepreneurs.

The business model of digitalization made women start from home and reached her targeted audience with the usage of the digital platform. The process of digitalization enables the startups and existing firms (Leong et al.,2016) and influence positively in every stage of the business to evolve entrepreneurship globally (Giones \& Brem, 2017).

H03: There is no significant relationship between motivation and digitalizing of women entrepreneurs.

H13: There is a significant relationship between motivation and digitalizing of women entrepreneurs.

Motivation towards digitalizing the business is the value-added process to attain the goal of women entrepreneurs. (Quagrainie \& Ariwa, 2017) identified as a major role of digital technologies for business and contributing factors for the financial improvement of the firm (Fazalbhoy, 2014). This study aims to investigate the impact of motivation on entrepreneurship, linking with the level of digitalization on women entrepreneur's firm performance.

H04: There is no significant mediation role of digitalization on the relationship between motivation and firm performance 
H14: There is a significant mediation role of digitalization on the relationship between motivation and firm performance

The effect of digitalization on the relationship between motivation and firm performance has been broadly investigated (Baron \& Kenny, 1986; Hasan \& Almubarak, 2016; Timothy Teo, 2013) with a mediating model for the process to examine the relationship between variables.

\section{METHODOLOGY}

This study focuses on the motivation, digitalization, and firm performance of women entrepreneurs. The structured approach was used in this study with four sections of the questionnaire, that is demographic variables to categorize responses women entrepreneurs in Bangalore (Müller, 2006), and with a five-point Likert scale used to measure motivation(Abeh et al., 2015; Krishnamoorthy \& Balasubramani, 2014; Müller, 2006), digitalization(Adams, Nelson, \& Todd, 1992; Hina, 2013; Lorz, 2011; Naser et al.,2012; Ndinguri, 2013; Ndubisi \& Sunway, 2005), and firm performance (Constantinidis et al.,2006; Hina, 2013; Karthik et al., 2015; Krishnamoorthy \& Balasubramani, 2014; Müller, 2006)of women entrepreneurs in Bangalore. The researcher selected Bangalore for the primary data of quantitative research, with a non-random sampling technique of 22 women entrepreneurs. After following up calls(Hina, 2013), with the agreement of each respondent for 30minutes recording interview and explained the purpose of the research that represents for the pilot study of the targeted sample size. This study demonstrates the cause and effect of motivation and digitalization on the firm performance of women entrepreneurs.

\section{RESULT AND ANALYSIS}

The Descriptive statistics for the demographic variables, the respondent of 22 women entrepreneurs between the age group of 20-60 were taken to analyze the data. Although most of the respondents were married $63 \%$, single never married $22 \%$ and others $13 \%$. Women to become independent, the significant results are high in various surveys that higher-level education encourages women to decide to become a successful entrepreneur(Naser et al., 2012).

Table 1 Descriptive Analysis of Women Entrepreneur's Profile

\begin{tabular}{|l|l|c|c|}
\hline \multicolumn{2}{|c|}{ Demographic Variables } & Frequency & Percentage (\%) \\
\hline \multirow{4}{*}{ Age } & Below 25 & 3 & 13.6 \\
\cline { 2 - 4 } & $26-35$ & 8 & 36.4 \\
\cline { 2 - 4 } & $36-45$ & 7 & 31.8 \\
\cline { 2 - 4 } & Above 46 & 4 & 18.2 \\
\hline \multirow{5}{*}{ Marital Status } & Single Never Married & 5 & 22.7 \\
\cline { 2 - 4 } & Married & 14 & 63.6 \\
\cline { 2 - 4 } & Widow & 1 & 4.5 \\
\cline { 2 - 4 } & Divorce & 2 & 9.1 \\
\hline \multirow{5}{*}{ Education Qualification } & Diploma course & 9 & 40.1 \\
\cline { 2 - 4 } & Bachelor Degree & 10 & 45.5 \\
\cline { 2 - 4 } & Master degree & 1 & 4.5 \\
\cline { 2 - 4 } & Doctorate & & \\
\hline
\end{tabular}


The Relationship of Motivation, Digitalization and Firm's Performance: A Study of Women Entrepreneurs in Bangalore

\begin{tabular}{|l|l|c|c|}
\hline \multirow{4}{*}{ Years of Experience } & Less than 2years & 5 & 22.7 \\
\cline { 2 - 4 } & 2 to less than 6 years & 7 & 31.8 \\
\cline { 2 - 4 } & 6 to less than 12 years & 4 & 18.2 \\
\cline { 2 - 4 } & 12 to less than 24 years & 4 & 18.2 \\
\cline { 2 - 4 } & more than 24 & 2 & 9.1 \\
\hline
\end{tabular}

Before inferential analysis, to test consistency between items in a scale Cronbach's Alpha was analyzed for reliability test(Cooper \& Schindler, 2014) and the items measure the degree to which instruments are homogeneous and reflect the similar causal assemble of items. As represented in table 2., the test resulted in $92 \%$ of motivation $94 \%$ of digitalization, and $89 \%$ of reliable data was used to analyze women entrepreneur's firm performance. The result of the t-test for the coefficient of correlation is at a $5 \%$ level of significance, it is shown that the relationship between different factors of motivation of women entrepreneurs.

Table 2 Reliability statistics and Correlations

\begin{tabular}{|l|l|l|l|l|}
\hline Pearson Correlation & Cronbach's Alpha & Motivation & Digitalization & Firm performance \\
\hline Motivation & 0.922 & 1 & & \\
\hline Digitalization & 0.941 & $.674^{* *}$ & 1 & \\
\hline Firm Performance & 0.894 & $.463^{*}$ & $.650^{* *}$ & 1 \\
\hline Mean & 75.77 & 116.45 & 34.5 \\
\hline Std. Deviation & & 17.696 & 23.05 & 4.964 \\
\hline **. Correlation is significant at the 0.01 level (2-tailed). \\
\hline$*$ *. Correlation is significant at the 0.05 level (2-tailed). \\
\hline
\end{tabular}

The coefficient of correlation is also at $5 \%$ significant, it is shown in table 2 , that the relationship between motivation, digitalization, and firm performance of women entrepreneurs. To test the cause and effect of motivation and digitalization on women entrepreneur's firm performance(Welsh et al., 2018), multiple regression analysis has been used (Hasan \& Almubarak, 2016) after the significant result of correlation.

Table 3 Summary of hypothesis statistical test - Regression Analysis

\begin{tabular}{|c|c|c|c|c|c|}
\hline $\begin{array}{c}\text { The effect of the mediating } \\
\text { variable }\end{array}$ & $\begin{array}{c}\text { Unstandardized } \\
\text { Coefficients }\end{array}$ & $\begin{array}{c}\text { Standardized } \\
\text { Coefficients }\end{array}$ & \multirow{2}{*}{$\begin{array}{c}\text { Sig. } \\
\text { (p- } \\
\text { value) }\end{array}$} & $\begin{array}{c}\text { Hypothesis } \\
\text { Accept or } \\
\text { Reject }\end{array}$ \\
\hline & Std. Error & Beta & & & \\
\hline $\begin{array}{c}\mathrm{H}_{01} \text { : There is no significant } \\
\text { relationship between } \\
\text { motivation and firm } \\
\text { performance of women } \\
\text { entrepreneurs }\end{array}$ & 0.06 & 0.46 & 2.33 & $0.03 *$ & $\begin{array}{c}\text { Rejected } \\
\text { Null } \\
\text { Hypothesis } \\
\text { at } 5 \% \text { level }\end{array}$ \\
$\begin{array}{c}\mathrm{H}_{11} \text { : There is a significant } \\
\text { relationship between } \\
\text { motivation and firm } \\
\text { performance of women } \\
\text { entrepreneurs }\end{array}$ & & & & & \\
\hline
\end{tabular}




\begin{tabular}{|c|c|c|c|c|c|}
\hline $\begin{array}{l}\mathrm{H}_{02} \text { : There is no significant } \\
\text { relationship between } \\
\text { digitalization and the firm } \\
\text { performance of women } \\
\text { entrepreneurs. } \\
\mathrm{H}_{12} \text { : There is a significant } \\
\text { relationship between } \\
\text { digitalization and the firm } \\
\text { performance of women } \\
\text { entrepreneurs. }\end{array}$ & 0.04 & 0.65 & 3.83 & $<0.01 * *$ & $\begin{array}{l}\text { Rejected } \\
\text { Null } \\
\text { Hypothesis } \\
\text { at } 1 \% \text { level }\end{array}$ \\
\hline $\begin{array}{l}\mathrm{H}_{03} \text { : There is no significant } \\
\text { relationship between } \\
\text { motivation and digitalizing of } \\
\text { women entrepreneurs. } \\
\mathrm{H}_{13}: \text { There is a significant } \\
\text { relationship between } \\
\text { motivation and digitalizing of } \\
\text { women entrepreneurs. }\end{array}$ & 0.22 & 0.67 & 4.08 & $<0.01 * *$ & $\begin{array}{l}\text { Rejected } \\
\text { Null } \\
\text { Hypothesis } \\
\text { at } 1 \% \text { level }\end{array}$ \\
\hline \multirow{2}{*}{$\begin{array}{c}\mathrm{H}_{04}: \text { There is no significant } \\
\text { mediation role of } \\
\text { digitalization on the } \\
\text { relationship between } \\
\text { motivation and firm } \\
\text { performance } \\
\mathrm{H}_{14} \text { : There is a significant } \\
\text { mediation role of } \\
\text { digitalization on the } \\
\text { relationship between } \\
\text { motivation and firm } \\
\text { performance }\end{array}$} & 0.07 & 0.04 & 0.19 & 0.85 & $\begin{array}{l}\text { Accepted } \\
\text { Null } \\
\text { Hypothesis } \\
\text { at } 5 \% \text { level }\end{array}$ \\
\hline & 0.05 & 0.62 & 2.63 & $0.02 *$ & $\begin{array}{l}\text { Rejected } \\
\text { Null } \\
\text { Hypothesis } \\
\text { at } 5 \% \text { level }\end{array}$ \\
\hline \multicolumn{6}{|c|}{$\begin{array}{l}\text { Note: When the p-value is** less than } 0.01 \text { denotes, highly significant - Reject the null hypothesis at } \\
\text { a } 1 \% \text { level, } \\
\text { The p-value is* between } 0.011 \text { to } 0.050 \text { denotes, significant - Reject the null hypothesis at } 5 \% \text { level } \\
\text { The p-value is more than } 0.05 \text { denotes, not significant -Accept the null hypothesis at } 5 \% \text { level. }\end{array}$} \\
\hline
\end{tabular}

Table 3 represents the result of this study that has been followed the review(Baron \& Kenny, 1986), to find the effect of the mediating variable the three sets of regression analyses have been conducted. As per the hypothesis testing, the regression table 3 shows the three conditions mentioned in mediation effect, to start with $\mathrm{H}_{1}$ the effect of motivation on firm performance of women entrepreneurs is significant ( $p$-value $=0.03, \beta=0.46$ ) accepted hypothesis at $5 \%$ level. The relationship between motivation and digitalization of women entrepreneurs is highly significant ( $\mathrm{p}$-value $=0.001, \beta=0.674$ ) at a $1 \%$ level. Then, the relationship between digitalization and firm performance of women entrepreneurs is highly significant ( $\mathrm{p}$ value $=0.001, \beta=0.650$ ) at a $1 \%$ level. The relationship between motivation and digitalization on firm performance of women entrepreneurs are not significant, as the motivation ( $p$ value $=0.851, \beta=0.045)$ and digitalization $(p$-value $=0.016, \beta=0.620)$ on firm performance of women entrepreneurs. Hence, the direct relationship of firm performance is positively associated with motivation and firm performance of women entrepreneurs. The mediating effect of digitalization between motivation and digitalization is not significant among women entrepreneurs in Bangalore. The below figure 1, represents the mediation model of digitalization between motivation and women entrepreneur's firm performance. This study 
attempt to generate a conceptual model that demonstrates the relationship of digitalization, motivation, and firm performance of women who own or manage the business in Bangalore.

\section{Digitalized Women Entrepreneurs: Conceptual Model}

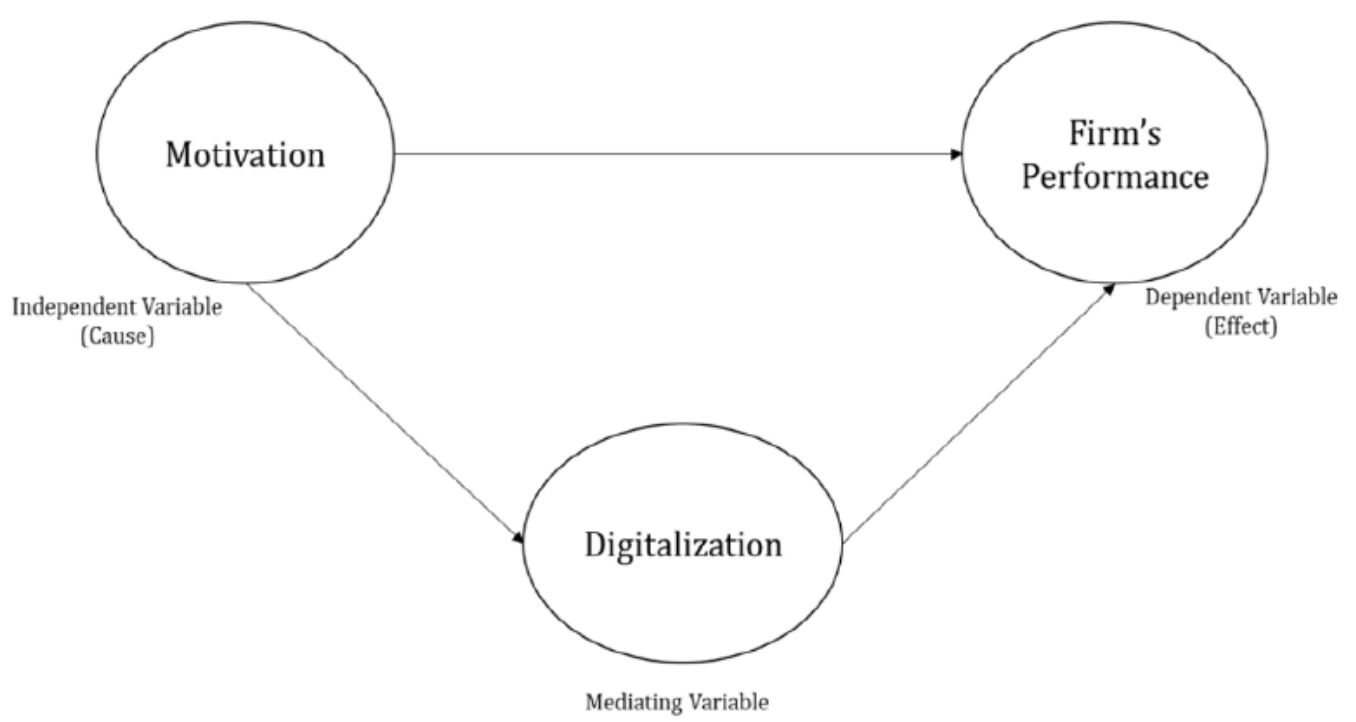

Figure 1 Conceptual model: Relationship of Motivation, Digitalization and firm's performance

\section{CONCLUSION}

This study resulted that digitalization was not a mediating variable in the relationship between the motivation and women entrepreneur's firm performance. The effects of the individual variable are highly significant by the motivation to firm performance, motivation to digitalization, and digitalization to firm performance. This study concludes that digitalization also one of the variables that control the firm performance of women entrepreneurs. Perhaps the analyses are suitable to the reality that the firm performance of women entrepreneurs is capable of doing business with digitalizing their business. The objective of the study has been achieved by analyzing the relationship of digitalization and motivation on women entrepreneur's firm performance. Finally, the women entrepreneurs are highly significant in the firm's performance with or without digitalization and satisfied with the outcome of their effort of starting their business.

\section{DIRECTIONS FOR THE FUTURE STUDY}

Even though the study, explores the relationship between motivation and digitalization on women entrepreneur's firm performance with the mediating variables. The structure of the model may have a moderating effect (Welsh et al.,2018)between motivation and digitalization to outperform the firm performance of women entrepreneurs. The researcher suggests that the model shall be constructed as a moderating variable to attract the women entrepreneurs for digitalization.

\section{REFERENCES}

[1] Abdul Al, R., \& Mostafa, R. (2019). Entrepreneurial Motivation and Firm Performance in Lebanon. Go-to-Market Strategies for Women Entrepreneurs, 157-171. https://doi.org/10.1108/978-1-78973-289-420191020 
[2] Abeh, A., Kadiri, U., \& Felicia, O. A. (2015). Family Factors and Women Entrepreneurial Motivation in Nigeria: A Survey of Selected Women Entrepreneurs in Kogi State. The IRES 19th International Conference, Dubai, (December), 66-70.

[3] Adams, D. A., Nelson, R., \& Todd, P. A. (1992). Perceived Usefulness, Ease of Use, and Usage of Information Technology: A Replication. In Source: MIS Quarterly (Vol. 16).

[4] Afework, G., Kassa, R., \& Satya, R. (2015). Performance-oriented factors for Women Entrepreneurs - A scale development perspective. Journal of Entrepreneurship in Emerging Economies, 7(2), 148-167.

[5] Ahmad Asadullah, Isam Faik, \& Atreyi Kankanhalli. (2018). Digital Platforms : A Review and Future Directions. PACIS Proceedings, (January), 1-14.

[6] Aparicio, S., Urbano, D., \& Audretsch, D. (2016). Institutional factors, opportunity entrepreneurship, and economic growth: Panel data evidence. Technological Forecasting and Social Change, 102, 45-61. https://doi.org/10.1016/j.techfore.2015.04.006

[7] Baron, R. M., \& Kenny, D. A. (1986). The Moderator-Mediator Variable Distinction in Social Psychological Research: Conceptual, Strategic, and Statistical Considerations. Journal of Personality and Social Psychology, 51(6), 1173-1182. https://doi.org/10.1007/BF02512353

[8] Baum, J. R., \& Locke, E. A. (2004). The relationship of entrepreneurial traits, skill, and motivation to subsequent venture growth. Journal of Applied Psychology, 89(4), 587-598. https://doi.org/10.1037/0021-9010.89.4.587

[9] Birley, S., Moss, C., \& Saunders, P. (1987). Do Women Entrepreneurs Require Different Training? American Journal of Small Business, 12(1), 27-35.

[10] Braun, P. (2008). Women entrepreneurs in the digital economy: What skills do they really need? 5th International Australian Graduate School of Entrepreneurship (AGSE) Entrepreneurship Research Exchange, 293-302. Retrieved from https://pdfs.semanticscholar.org/28ab/5a278c1f8532e36278fdda037e52f1b30da5.pdf

[11] Chaithralaxmi.T and Shruthi. N. (2016). E-Commerce In India - Opportunities. International Journal of Latest Trends in Engineering and Technology, 505-510.

[12] Chell, E., Wicklander, D. E., Sturman, S. G., \& Hoover, L. W. (2008). The Entrepreneurial Personality. The Entrepreneurial Personality. https://doi.org/10.4324/9780203938638

[13] Constantinidis, C., Cornet, A., \& Asandei, S. (2006). Financing of women-owned ventures: The impact of gender and other owners- and firm-related variables. Venture Capital, 8(2), 133-157. https://doi.org/10.1080/13691060600572557

[14] Cooper, D. R., \& Schindler, P. S. (2014). Business research methods.

[15] Dempsey, D. M. (2014). The push and pull of entrepreneurial careers: Reflections on entrepreneurial self-efficacy (University of Alberta Libraries; Vol. 77). Retrieved from http://ovidsp.ovid.com/ovidweb.cgi?T=JS\&PAGE=reference\&D=psyc14\&NEWS=N\&AN=2 016-53068-036

[16] Fazalbhoy, S. (2014). Women Entrepreneurship as the Way for Economic Development. Annual Research Journal of SCMS, Pune, 2(1), 117-127. Retrieved from https://scmspune.ac.in/chapter/pdf/Chapter 10.pdf 
The Relationship of Motivation, Digitalization and Firm's Performance: A Study of Women Entrepreneurs in Bangalore

[17] Giones, F., \& Brem, A. (2017). Digital Technology Entrepreneurship: A Definition and Research Agenda. Technology Innovation Management Review, 7(5), 44-51. https://doi.org/10.22215/timreview1076

[18] Goyal, M., \& Parkash, J. (2011). Women Entrepreneurship in India - Problems and Prospects. ZENITH International Journal of Multidisciplinary Research, 1(5). https://doi.org/10.2139/ssrn.3110340

[19] Hasan, F. S. M. A., \& Almubarak, M. M. S. (2016). Factors Influencing Women Entrepreneurs ' Performance in SMEs. World Journal of Entrepreneurial, Management and Sustainable Development, 12(November), 21.

[20] Haverson, W. W. (1993). A Conceptual Model of Women Entrepreneurs in Small Businesses.

[21] Hina, S. (2013). Creating an Enabling Environment for Women' S Entrepreneurship in India. Economic and Social Commission for Asia and the Pacific, (May), 68.

[22] Jason Bloomberg. (2018). Digitization, Digitalization, And Digital Transformation: Confuse Them At Your Peril. Retrieved from https://www.forbes.com/sites/jasonbloomberg/2018/04/29/digitization-digitalization-anddigital-transformation-confuse-them-at-your-peril/\#78e $677 \mathrm{fd} 2 \mathrm{f} 2 \mathrm{c}$

[23] Kain, P., \& Sharma, M. (2013). Women Entrepreneurship education need for today. Apeejay Journal of Management Sciences And Technology, 1(1), 134-140.

[24] Karthik, D., George, R., \& Singla, C. (2015). International Diversification and Firm Performance : The Contingent Influence of Product Diversification.

[25] Krishnamoorthy, V., \& Balasubramani, R. (2014). Motivational Factors Among Women Entrepreneurs and Their Entrepreneurial Success: a Study. International Journal of Management Research and Business Strategy, 3(2). Retrieved from http://www.ijmrbs.com/currentissue.php

[26] Krishnan, L., \& Kamalanabhan, T. (2013). Entrepreneurial success and life satisfaction among women entrepreneurs in micro-enterprises. South Asian Journal of ..., 20(2), 40-63. Retrieved from http://search.proquest.com.scihub.io/openview/17ebb92b1be58d7fe43cda450353c746/1?pq-origsite=gscholar

[27] Leong, C., Pan, S. L., \& Liu, J. (2016). Digital Entrepreneurship of Born Digital and Grown Digital Firms : Comparing the Effectuation Process of Yihaodian and Suning. Thirty-Seventh International Conference on Information Systems, Dublin 2016, 1-11.

[28] Lorz, M. (2011). The Impact of IT-based Entrepreneurship Education on Entrepreneurial Intention. https://doi.org/10.1111/jsbm.12065

[29] Mohammed, K., Izwar, H. I., \& Anuar, K. M. S. (2017). Empirical evidence of entrepreneurial competencies and firm performance: a study of women entrepreneurs of Nigeria. International Journal of Entrepreneurial Knowledge Issue, 5(1), 49-61. https://doi.org/10.1515/ijek-20170005

[30] Müller, C. (2006). Factors Affecting Women Entrepreneurs in Establishing and Expanding their Businesses in NAD Province. In International Labour Organization.

[31] Naffziger, D. W., Hornsby, J. S., \& Kuratko, D. F. (1994). A Proposed Research Model of Entrepreneurial Motivation. Entrepreneurship Theory and Practice, 18(3), 29-42. https://doi.org/10.1177/104225879401800303 
[32] Nambisan, S. (2017). Digital Entrepreneurship: Toward a Digital Technology Perspective of Entrepreneurship. Entrepreneurship: Theory and Practice, 41(6), 1029-1055. https://doi.org/10.1111/etap.12254

[33] Naser, K., Nuseibeh, R., \& Al-Hussaini, A. (2012). Personal and External Factors Effect on Women Entrepreneurs: Evidence From Kuwait. Journal of Developmental Entrepreneurship, 17(02), 1250008. https://doi.org/10.1142/S1084946712500082

[34] Ndinguri, E. (2013). Use and Access of Emerging Technology Impact: A Study of Startup Women Entrepreneurs in the United States (Louisiana State University and Agricultural and Mechanical College). Retrieved from http://digitalcommons.1su.edu/cgi/viewcontent.cgi?article=3516\&context=gradschool_disserta tions

[35] Ndubisi, N. O., \& Sunway, B. (2005). Effect of perception and personal traits on computer technology acceptance by women entrepreneurs in Malaysia. Journal of Asia Entrepreneurship and Sustainability, 1(1), 1-29. Retrieved from http://www.asiaentrepreneurshipjournal.com/AJESI1Ndubisi.pdf

[36] Örnek, A. S., \& Danyal, Y. (2015). Increased Importance of Entrepreneurship from Entrepreneurship to Techno-Entrepreneurship (Startup): Provided Supports and Conveniences to Techno-Entrepreneurs in Turkey. Procedia - Social and Behavioral Sciences, 195, 11461155. https://doi.org/10.1016/j.sbspro.2015.06.164

[37] Pruett, M. (2012). Entrepreneurship Education: Workshops and Entrepreneurial Intentions. Journal of Education for Business, 87(2), 94-101. https://doi.org/10.1080/08832323.2011.573594

[38] Quagrainie, F. A., \& Ariwa, E. (2017). Effective deployment of digital technologies for business enterprise in Sub-Sahara Africa: Implications for women entrepreneurs e-readiness for Internet usage in Ghana? 2016 6th International Conference on Innovative Computing Technology, INTECH 2016, 63-71. https://doi.org/10.1109/INTECH.2016.7845131

[39] Semrau, T., Ambos, T., \& Kraus, S. (2016). Entrepreneurial orientation and SME performance across societal cultures: An international study. Journal of Business Research, 69(5), 19281932. https://doi.org/10.1016/j.jbusres.2015.10.082

[40] Simón-Moya, V., Revuelto-Taboada, L., \& Fernández Guerrero, R. (2020, January 1). Corrigendum to "Institutional and economic drivers of entrepreneurship: An international perspective" Journal of Business Research, Vol. 108, p. 509. https://doi.org/10.1016/j.jbusres.2017.08.004

[41] Sugiharto, Toto; Suhendra Euphrasia Susy; Hermana, B. (2010). Information Technology and Business Performance: A Case Study on Small Food Processing Firms. Journal Of Global Business Administration - March 2010 Volume 2, Number1, 2(March), 84-95.

[42] Susan Moore. (2015). Digitalization or Automation - Is There a Difference? - Smarter. Retrieved August 21, 2020, from Gartner website: https://www.gartner.com/smarterwithgartner/digitalization-or-automation-is-there-adifference/

[43] Timothy Teo. (2013). Handbook of Quantitative Methods for Educational Research.

[44] Welsh, D. H. B., Kaciak, E., Memili, E., \& Minialai, C. (2018). Business-family interface and the performance of women entrepreneurs: The moderating effect of economic development. 
The Relationship of Motivation, Digitalization and Firm's Performance: A Study of Women Entrepreneurs in Bangalore

International Journal of Emerging Markets, 13(2), 330-349. https://doi.org/10.1108/IJoEM-032017-0095

[45] Welsh, D. H. B., Kaciak, E., Memili, E., Welsh, C. M., Kaciak, D. H., \& Memili, E. (2018). Business-family interface and the performance of women entrepreneurs: The moderating effect of economic development. International Journal of Emerging Markets, 13(2), 330-349. https://doi.org/10.1108/IJoEM-03-2017-0095

[46] William J Health. (1995). Perceived educational needs of women entrepreneurs in a Business Incubator setting.

[47] Yan, J. (2010). The impact of entrepreneurial personality traits on the perception of new venture opportunity. New England Journal of Entrepreneurship, 13(2), 21-35. https://doi.org/10.1108/neje-13-02-2010-b002

[48] Yukongdi, V. (2020). The Influence of Family, Human, Social Capital \& Government Support Services on Women Entrepreneurial Start-up Decisions: A Qualitative Study. Review of Integrative Business and Economics Research, 9(1), 307-319.

[49] Zizile, T., \& Tendai, C. (2018). The importance of entrepreneurial competencies on the performance of women entrepreneurs in South Africa. Journal of Applied Business Research, 34(2), 223-236. https://doi.org/10.19030/jabr.v34i2.10122

[50] Knowledge Management, 2(3), 1-7. 